oril
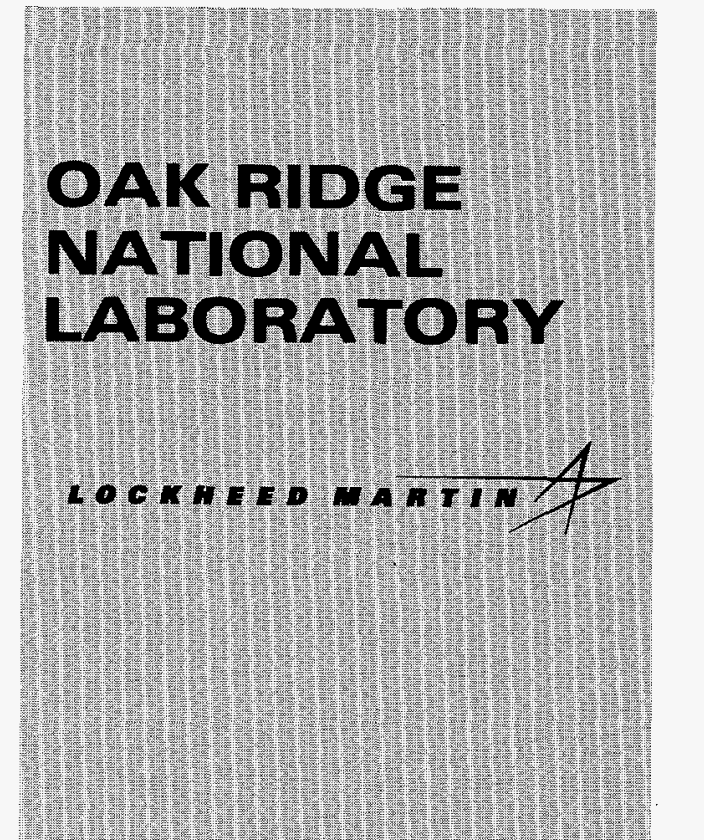$$
\text { 畨 }
$$$$
\theta^{2}
$$

WANAGED ANO OPERATED BY

OCKHEED WARTIN ENERGY RESEARCH CORPORATION FOR THE UNTED STATES

DEPARTMENT OF ENERGY
ORNL/M- - 6/35

APPROVED FOR PUBLIC RELEASE

C/ORNL95-0397

\author{
CRADA Final Report \\ for \\ CRADA Number ORNL95-0397
GELCASTING CERAMIC DEFENSE PARTS

Mark A. Janney

Oak Ridge National Laboratory

Anthony T. Jankiewicz

Hughes Missile Systems Company

Prepared by the

Oak Ridge National Laboratory

Oak Ridge, Tennessee 37831 managed by

Lockheed Martin Energy Research

Corporation

for the

U.S. Department of Energy

under contract DE-AC05-96OR22464

APPROVED FOR PUBLIC RELEASE

\section{UNLIMITED DISTRIBUTION}


This report has been reproduced directly from the best available copy.

Available to DOE and DOE contractors from the Office of Scientific and Technical Information, P. O. Box 62, Oak Ridge, TN 37831; prices available from (423) 576-8401, FTS 626-8401.

Available to the public from the National Technical Information Service, U.S. Department of Commerce, 5285 Port Royal Road, Springfield, VA 22161.

This report was prepared as an account of work sponsored by an agency of the United States Government. Neither the United States Government nor any agency thereof, nor any of their employees, makes any warranty, express or implied, or assumes any legal liability or responsibility for the accuracy, completeness, or usefulness of any information, apparatus, product, or process disclosed, or represents that its use would not infringe privately owned rights. Reference herein to any specific commercial product, process, or service by trade name, trademark, manufacturer, or otherwise, does not necessarily constitute or imply its endorsement, recommendation, or favoring by the United States Government or any agency thereof. The views and opinions of authors expressed herein do not necessarily state or reflect those of the United States Government of any agency thereof. 


\author{
CRADA Final Report \\ for \\ CRADA Number ORNL 95-0397
}

\title{
GELCASTING CERAMIC DEFENSE PARTS
}

\author{
Mark A. Janney \\ Oak Ridge National Laboratory \\ Anthony T. Jankiewicz \\ Hughes Missile Systems Company \\ Prepared by the \\ Oak Ridge National Laboratory \\ Oak Ridge, Tennessee 37831 \\ managed by \\ Lockheed Martin Energy Research Corporation \\ for the \\ U.S. Department of Energy \\ under contract DE-AC05-96OR22464
}

Unlimited Distribution 


\section{DISCLAMIER}

Portions of this document may be illegible in electronic image produets. Images are produced from the best available original document. 
CONTENTS

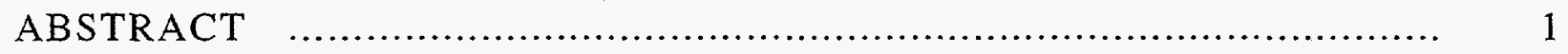

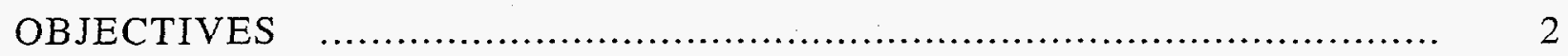

TECHNICAL DISCUSSION …...................................................... 3

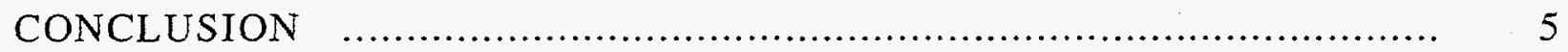

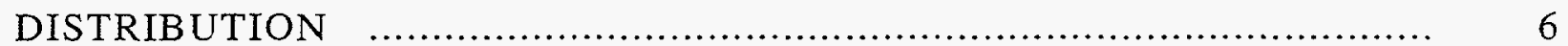




\section{ABSTRACT}

The goal of this work was to demonstrate an ability to gelcast and fire a particular defense-related part to net shape and to hold the required tolerances on size and shape with minimal or no post firing machining. The precision required represents a huge increase in the precision currently achievable by standard ceramic processing.

The project has produced very promising results. While we did not achieve the degree of precision in as-fired parts that we had targeted $( \pm 0.025 \%)$, we did improve our ability to hold tolerances to the $\pm 0.25 \%$ level from our initial level of $\pm 2.5 \%$ on parts that were 5 to 10 inches in diameter. The progress to date makes us believe that the ultimate goal is achievable.

We have demonstrated that gelcasting can be a viable precision forming technique for large articles. We are currently working with our industrial partner on a Statement of Work for a follow on project. This will be either a CRADA or a WFO project. The anticipated funding level is one person year in 1997 with funds coming from the industrial partner. Assuming reasonable progress is made in 1997, additional projects of similar size are expected in 1998 and out years funded either by the industrial partner or by DOD. 


\section{OBJECTIVES}

Approximately $75 \%$ of the cost of fabricating the defense parts of interest is in machining. Further, the next generations of materials will be required to be harder to meet erosion and impact requirements that will result in additional machining cost. Hughes has developed a trade secret slip cast process and material capable of next generation performance. Economic processing cannot be done with this material because of excessive machining costs.

Gelcasting is a net to near net casting process for ceramics. Joining of this casting process with the proofed defense material should eliminate or significantly reduce machining costs. Goals of the project are to develop a gelcasting process for this material and provide structural and electrical specimen as well as provide a generic test article to the configuration of the product.

\section{Were the objectives of the CRADA met?}

The objectives of the CRADA were met.

How did the work done under the CRADA benefit the DOE office that funded the CRADA in pursuing its mission?

This was a $100 \%$ Funds-in CRADA so no DOE office was involved. 


\section{TECHNICAL DISCUSSION}

The initial phase of development began in August 1995. We first had to demonstrate an ability to gelcast the Hughes ceramic composition. Hughes came to us with a system based on materials and processes developed in the early 1980's. The system presented to us for consideration was clearly not "state of the art." Much had been learned about, and developed in, advanced ceramics in the intervening years. Therefore, our first task was to convince Hughes that there were better raw materials for the ceramic and better ways to process those materials. Having convinced Hughes of the need for changes, we next had to develop a gelcasting system that would produce a fired material with properties equal to those possessed by the initial Hughes material.

A joint effort by ORNL and Hughes personnel advanced the process significantly. During the second phase of work we achieved five main goals. First, we developed binder burnout and firing schedules that produced ceramic parts with appropriate density. Second, we conducted $\mathrm{x}$ ray phase analysis and electrical properties evaluations on gelcast and fired ceramic to show that its properties were similar to the original material developed at Hughes. Third, we scaled up the gelcasting process to batches large enough $(5 \mathrm{~kg})$ to produce full-size parts. Fourth, we developed initial procedures and hardware for firing full-scale parts. And, fifth, we gelcast and fired five full scale parts.

At the end of the second phase of the work, we had produced one full-size part that was structurally sound and several full size parts that had various structural defects. Subsequent analysis of the one good part showed that the phase composition and the electrical properties of the fired part were somewhat off specification; this was caused by small differences in the firing conditions between the lab furnace used for the initial work and the production furnace used for firing the full sized parts. Furthermore, the one good part was dimensionally out of tolerance by several percent. Therefore, Hughes could not conduct an evaluation of the performance of the new part.

The final phase of the project was aimed at fine tuning the gelcasting and firing processes for ceramic parts to produce repeatable, high quality, close tolerance parts. This involved improving the gelcasting process to produce better quality green parts and improving the firing process to produce fired parts having better as-fired dimensional control.

It had been observed in other investigations that some gelcast systems release better from anodized aluminum molds than from aluminum metal molds. We were able to greatly improved the performance of the Hughes part mold by anodizing it. We further improved the release of the part from the mold by finding a better mold release than that used in the initial evaluation. This was accomplished by conducting an extensive set of experiments using a matrix of mold release conditions. This is really the only way to determine mold - gelcasting slurry - mold release interactions. The number of factors involved is large and the understanding of each factor and how it interacts with the others is highly limited.

Parts gelcast using these new procedures were very much easier to process. There were essentially no failures in drying because of cracking, warping, or sticking. This had been a major problem in the earlier phase of the project. The excellent release of the part from the mold and mandrel meant that there were essentially no strains generated in the part during unmolding. This resulted in a dried green part that was crack free and distortion free.

Hughes suggested that we fire the best parts using a proprietary technique they had developed previously. It was hoped that using this procedure would produce a surface that was close enough in dimensions to the requirements that no machining would be required. 
Firing tests were conducted and the procedure produced promising results on the full sized parts. The parts fired using Hughes proprietary firing technique were significantly more consistent than those fired conventionally. We achieved as-fired tolerances on the order of $\pm 0.25 \%$. This was far better than the tolerances achieved in our initial trials $( \pm 2 \%)$. However, we still have a way to go to reach the desired fired tolerances of $\pm 0.025 \%$.

Hughes is currently getting ready to test the best part that was made. They will machine the part to the appropriate tolerances and then conduct their tests.

\section{Inventions}

No inventions were made during the CRADA.

Any plans for future collaboration.

Hughes is pleased with the progress that we have made on the gelcasting project. We are currently working with Hughes on a Statement of Work for a follow on project. This will be either a CRADA or a WFO project. The anticipated funding level is one person year in 1997 with funds coming from Hughes. Assuming reasonable progress is made in 1997, additional projects are expected in 1998 and out years funded either by Hughes or by DOD.

\section{Assessment of commercialization possibilities}

An assessment of commercialization will have to wait for the results of the additional collaborations that are planned. It is too early to make comment at this point. 


\section{CONCLUSIONS}

We have demonstrated that large defense-related ceramic parts can be fabricated using the gelcasting process. Promising results were achieved regarding producing parts with closely controlled tolerances. Though we did not achieve the level of tolerance desired, we are encouraged that those tolerances can be achieved with additional study. 


\section{DISTRIBUTION}

1-2. Office of Scientific and Technical Information, P.O. Box 62, Oak Ridge, TN 37831

3. Work for Others Office, DOE-ORO, ER-113, P.O. Box 2001, Oak Ridge, TN 37831

4. P. L. Gorman, DOE-ORO, ORNL Site Office, P.O. Box 2008, Oak Ridge, TN 37831 6269

5. Tony Jankiewicz, Hughes Missile Company, P.O. Box 11337, Bldg. 802, MS F5, Tucson, AZ 85734

6. R. A. Bradley

7. R. L. Beatty

8. D. F. Craig

9. D. R. Hamrin

10-20. M. A. Janney

21. R. J. Lauf

22. A. J. Luffman

23. C. A. Valentine 